\title{
Calsyntenin-1 Regulates Targeting of Dendritic NMDA Receptors and Dendritic Spine Maturation in CA1 Hippocampal Pyramidal Cells during Postnatal Development
}

\author{
Jeanne Ster, ${ }^{1}$ Martin Steuble, ${ }^{2}$ Clara Orlando, ${ }^{1}$ Tu-My Diep, ${ }^{2}$ Alexander Akhmedov, ${ }^{2}$ Olivier Raineteau, ${ }^{1}$ \\ Vincent Pernet, ${ }^{1}$ Peter Sonderegger, ${ }^{2}$ and Urs Gerber ${ }^{1}$ \\ ${ }^{1}$ Brain Research Institute and ${ }^{2}$ Department of Biochemistry, University of Zurich, CH-8057 Zurich, Switzerland
}

\begin{abstract}
Calsyntenin-1 is a transmembrane cargo-docking protein important for kinesin-1-mediated fast transport of membrane-bound organelles that exhibits peak expression levels at postnatal day 7. However, its neuronal function during postnatal development remains unknown. We generated a knock-out mouse to characterize calsyntenin-1 function in juvenile mice. In the absence of calsyntenin-1, synaptic transmission was depressed. To address the mechanism, evoked EPSPs were analyzed revealing a greater proportion of synaptic GluN2B subunit-containing receptors typical for less mature synapses. This imbalance was due to a disruption in calsyntenin-1-mediated dendritic transport of NMDA receptor subunits. As a consequence of increased expression of GluN2B subunits, NMDA receptor-dependent LTP was enhanced at Schaffer collateral-CA1 pyramidal cell synapses. Interestingly, these defects were accompanied by a decrease in dendritic arborization and increased proportions of immature filopodialike dendritic protrusions at the expense of thin-type dendritic spines in CA1 pyramidal cells. Thus, these results highlight a key role for calsyntenin-1 in the transport of NMDA receptors to synaptic targets, which is necessary for the maturation of neuronal circuits during early development.
\end{abstract}

Key words: CA1 pyramidal cells; calsyntenin-1; GluN2B subunit; NMDA receptors; receptor targeting; spine maturation

\section{Introduction}

The calsyntenins (calsyntenin-1, calsyntenin-2, and calsyntenin-3) are a family of neuronally expressed proteins that belong to the cadherin superfamily of cell adhesion molecules (Vogt et al., 2001). In situ hybridization in the mouse brain reveals a distinct expression pattern for each form of calsyntenin. In the hippocampus, pyramidal neurons of the CA1 region and granule cells of the dentate gyrus express predominantly calsyntenin-1, while pyramidal neurons of the CA3 region express similar levels of all three calsyntenins (Hintsch et al., 2002). The cytosolic segment of the calsyntenins interacts directly with the light chain of kinesin-1 via the conserved L/M-E/D-W-D-D-S motif (Konecna et al., 2006; Araki et al., 2007). Through this interaction, calsyntenins play an essential role in kinesin-1-dependent fast vesicular

\footnotetext{
Received Jan. 13, 2014; revised May 2, 2014; accepted May 19, 2014.

Author contributions: J.S., P.S., and U.G. designed research; J.S., M.S., C.O., T.-M.D., A.A., O.R., and V.P. performed research; J.S., M.S., C.O., V.P., and P.S. analyzed data; J.S., P.S., and U.G. wrote the paper.

This work was funded by the Swiss National Science Foundation, the Swiss Foundation for Excellence and Talent in Biomedical Research, and the Novartis Foundation for Medical Biological Research. We are grateful for expert technical assistance from F. David, D. Göckeritz-Dujmovic, H. Kasper, B. Kunz, S. Giger, and P. Morciano. We thank Mitsuo Tagaya for kindly providing anti-Rip11. We thank Oliver Weinmann and Serguei Kozlov for advice and technical help; Philipp Schätzle for help with genotyping; and Beat Gähwiler, Björn Kampa, and Fabienne Loup for critically reading this manuscript.

The authors declare no competing financial interests.

Correspondence should be addressed to Urs Gerber, Brain Research Institute, University of Zurich, Winterthurerstrasse 190, CH-8057 Zurich, Switzerland. E-mail: gerber@hifo.uzh.ch.

DOI:10.1523/JNEUROSCI.0144-14.2014

Copyright $\odot 2014$ the authors $\quad 0270-6474 / 14 / 348716-12 \$ 15.00 / 0$
}

transport (Konecna et al., 2006). Using organelle immunoisolation and proteomics, we demonstrated that calsyntenin-1 organelles contain components characteristic of vesicles of endosomal pathways (Steuble et al., 2010). Axons of hippocampal neurons transport at least two distinct, nonoverlapping calsyntenin1-containing cargo packages: one characterized as early endosomal, amyloid precursor protein (APP) positive, the other as recyclingendosomal, APP negative (Ludwig et al., 2009). Calsyntenin-1 is also essential for the segregation and concentration of molecular cargo at export domains of the trans-Golgi network (TGN). For example, calsyntenin-1 is involved in the exit of APP from the TGN (Ludwig et al., 2009) and its subsequent anterograde axonal transport (Ludwig et al., 2009; Steuble et al., 2010, 2012; Vagnoni et al., 2012). Evidence for a synaptic role of calsyntenins was provided by a study in which a mutation in a nematode ortholog of calsyntenin resulted in impaired associative learning (Hoerndli et al., 2009), and genetic linkage studies indicate that calsyntenin-2 is involved in episodic memory performance in human subjects (Papassotiropoulos et al., 2006). In this respect, the strong immunoreactivity for calsyntenin-1 in the gray matter (Konecna et al., 2006) suggests a role for calsyntenin-1 not only in axonal but also in dendritic vesicular transport.

To characterize potential synaptic functions of calsyntenin-1, we compared responses in wild-type (WT) and a calsyntenin-1 knock-out (Cst-1 KO) mouse that we generated. Our data indicate that calsyntenin-1 regulates the timely development of synapses and dendritic spines by ensuring rapid trafficking of NMDA receptor subunits to synapses. 


\section{Materials and Methods}

Generation and characterization of Cst-1 KO mice. A lambda library of genomic fragments from a C57BL/6 mouse strain was screened with a ${ }^{32} \mathrm{P}$-labeled hybridization probe comprising the cytoplasmic domain of calsyntenin-1. Of the several overlapping fragments identified, an $18.9 \mathrm{~kb}$ fragment containing exons 17,18 , and 19 , covering the coding sequences for the transmembrane and cytoplasmic domains, was chosen for generation of the targeting construct. The left arm of homology was isolated as a $6.8 \mathrm{~kb}$ long EcoRI/SalI restriction fragment. The loxP site was excised as SmaI/HindIII from pBS KS loxPE1 and inserted as the orphan loxP site into the SmaI site within intron 16 of the left arm. The right arm of homology consisted of a $6.3 \mathrm{~kb}$ SalI fragment, which was subcloned into SalI/XhoI digested pBC KS(-) (Stratagene). The floxed neo cassette was cloned as a blunted $2.2 \mathrm{~kb}$ BamHI/XhoI restriction fragment from pSKloxPneoloxP into the blunted SfiI site 200 bp downstream of the last exon of calsyntenin-1. This intermediate was digested with ClaI (in vector backbone), filled, and redigested with SalI to enable the insertion of the previously prepared left arm construct as a DraI/SalI fragment. The negative selection marker, in the form of a $1.2 \mathrm{~kb}$ NotI/Bsp120I fragment from $\mathrm{p} \# 8 \mathrm{DT} \alpha$, was inserted into NotI of the vector backbone. Vector linearization was done by double digestion with NotI/AatII. The resulting targeting construct consisted of two long arms of homology, with an orphan loxP site upstream of exon 17 and a loxP-flanked neo cassette downstream of the last exon.

The linearized targeting vector was electroporated into B6III embryonic stem cells (from the C57BL/6 mouse line) and clones were selected positively for neomycin resistance with G418 (Geneticin; Life Technologies). Clones were screened for homologous recombination by Southern blot analysis using EcoRI digestion and a combination of PCR-generated $800 \mathrm{pb}$ hybridization probes with (1) a short sequence upstream of the left arm of homology in intron 11, (2) the neo cassette, and (3) a sequence downstream of exon 19 within the right arm of homology. Embryonic stem (ES) cells with appropriate targeting were injected into CB.20 blastocysts. Resulting chimeric offspring had a white background (CB.20 host) with black chimerism. When bred with C57BL/6 mice, the ES cellderived offspring were black. The LoxP-flanked region including exons 17-19 was deleted by breeding these conditional Cst-1 KO mice with a transgenic mouse expressing Cre recombinase under the control of the ubiquitously active EIIa promoter (EIIa-Cre mice). Interbreeding of these first generation progeny resulted in efficient germline transmission of the deletion to subsequent generations.

Progeny were screened by Southern hybridization and genomic PCR for successful deletion and germline transmission. Southern blot analysis confirmed that the $8.7 \mathrm{~kb}$ EcoRI-fragment spanning this genomic region in WT mice was replaced by a $1.8 \mathrm{~kb}$ fragment, attributable to the presence of an EcoRI site in the sole loxP site remaining after Cre/loxP-based deletion of the loxP-flanked region (see Fig. 1A). Successful deletion of the loxP-flanked segment comprising the transmembrane and cytoplasmic domains was confirmed by PCR of genomic DNA of WT, heterozygous, and homozygous Cst-1 KO mice. Only WT and heterozygous Cst-1 KO mice showed the $225 \mathrm{bp}$ amplicon, because one of the primers was located within exon 19 that was deleted in the Cst-1 KO allele (Fig. 1B). A further round of PCR with another pair of primers, located up and downstream of the segment to be deleted, resulted in the expected truncated $560 \mathrm{bp}$ amplicon, thus confirming successful deletion. Northern blots of isolated polyadenylated mRNA from brain homogenates showed a truncated transcript in mice containing the Cst- $1 \mathrm{KO}$ allele, indicating a stable transcript with the polyadenylation site located downstream of the still present sole loxP site (Fig. 1C). RT-PCR demonstrated a truncation by $\sim 0.7 \mathrm{~kb}$, which corresponds to the length of the coding sequences of exons 17-19 (Fig. 1C).

In all experiments we compared transgenic mice $(n=70)$ with nontransgenic littermates $(n=88)$ of either sex.

Tissue preparation. Acute slices were prepared from juvenile mice (P15-P21) and adult mice (2 months old) following a protocol approved by the Veterinary Department of the Canton of Zurich. Mice were decapitated, and brains quickly removed and chilled in cold artificial CSF (ACSF) containing the following (in $\mathrm{mm}$ ): $125 \mathrm{NaCl}, 2.5 \mathrm{KCl}, 1.25$
$\mathrm{NaH}_{2} \mathrm{PO}_{4}, 25 \mathrm{NaCHCO}_{3}, 1 \mathrm{MgCl}_{2}, 2 \mathrm{CaCl}_{2}$, and 10 glucose, pH 7.4, equilibrated with $95 \% \mathrm{O}_{2}$ and $5 \% \mathrm{CO}_{2}$. Acute 350 - $\mu$ m-thick slices were prepared with a vibratome (HM 650V, Microm International) in icecold ACSF. Sections were incubated in ACSF at $34^{\circ} \mathrm{C}$ for $20 \mathrm{~min}$ and then kept at room temperature for at least $1 \mathrm{~h}$ before recording.

Electrophysiology. Acute slices were transferred to a recording chamber mounted on an upright microscope (Axioskop FS1; Zeiss) and superfused with $\mathrm{ACSF}$ at $27^{\circ} \mathrm{C}$. A monopolar electrode was placed in the Schaffer collaterals, and stimulation was applied at $0.033 \mathrm{~Hz}$ with stimulus intensity ranging from 10 to $60 \mu \mathrm{A}$, yielding evoked field EPSPs (fEPSPs) of $0.2-1 \mathrm{~V}$. Baseline fEPSPs were recorded for a minimum of $20 \mathrm{~min}$. LTP was induced by stimulation with $100 \mathrm{~Hz}$ for one train or three trains of $1 \mathrm{~s}$ duration separated by $20 \mathrm{~s}$ (high-frequency stimulation; HFS), four stimuli at $100 \mathrm{~Hz}$ for 10 bursts separated by $200 \mathrm{~ms}$ (theta-burst stimulation; TBS). For LTD Schaffer collaterals were stimulated at $1 \mathrm{~Hz}$ for $15 \mathrm{~min}$ (low-frequency stimulation; LFS). Data were analyzed by measuring the slope of individual fEPSPs.

Whole-cell patch-clamp recordings were obtained from CA1 pyramidal cells using an Axopatch 200B amplifier (Molecular Devices). Patch recording pipettes $(4-5 \mathrm{M} \Omega$ ) were filled with intracellular solution containing the following (in mM): $120 \mathrm{CsMeSO}_{4}, 10 \mathrm{CsCl}_{2}, 10 \mathrm{HEPES}, 2$ $\mathrm{MgCl}_{2}, 4 \mathrm{NaATP}, 0.4 \mathrm{NaGTP}, 5 \mathrm{Na}$-creatine, and 10 EGTA, pH 7.2. Biocytin was added to the patch solution at a concentration of $2 \mu \mathrm{g} / \mathrm{ml}$.

EPSCs were evoked by electrical stimulation of Schaffer collateral/ commissural axons using a bipolar-stimulating electrode placed in the stratum radiatum of CA1 $(0.033 \mathrm{~Hz}$ stimulation frequency). AMPAmediated EPSCs and NMDA-mediated EPSCs were obtained at $-70 \mathrm{mV}$ and $+30 \mathrm{mV}$, respectively, in the presence of picrotoxin $(50 \mu \mathrm{M})$.

Evoked current and spontaneous activities were analyzed offline using pClamp 10 (Molecular Devices). All data are reported as the mean \pm SEM. Statistical comparisons were made using two-tailed unpaired or paired Student's $t$ tests. For comparisons of cumulative distributions of amplitude and interevent interval of EPSCs we used the Kolmogorov-Smirnov test. All compounds were bath applied 20 min before induction of LTP.

Spine imaging and analysis. Slices fixed with $4 \%$ paraformaldehyde were extensively washed in $0.1 \mathrm{M} \mathrm{PB}$. After blocking in $0.1 \mathrm{M}$ PB supplemented with $0.4 \%$ Triton X-100 and $10 \%$ inactivated horse serum for $2 \mathrm{~h}$ at room temperature, slices were incubated with Streptavidin Alexa Fluor 488 ( $4 \mu \mathrm{g} / \mathrm{ml}$, Invitrogen) for $2 \mathrm{~h}$ at room temperature. Slices were counterstained with DAPI (Invitrogen), washed in $0.1 \mathrm{M} \mathrm{PB}$, and mounted onto gelatin-coated slides with Vectashield-mounting medium (Reactolab) to preserve fluorescent labeling. Images of CA1 apical dendrites in the stratum radiatum were acquired using a Leica TCS SPE II confocal microscope. Dendritic spines were visualized by using the $488 \mathrm{~nm}$ laser line, with a $63 \times / 1.4$ oil objective and an additional magnification of $8 \times$. Stacks of images $(512 \times 512$ pixels $)$ were collected with a $z$-step size of 0.2 $\mu \mathrm{m}$. Images were deconvolved using Huygens Software (Scientific Volume Imaging) and analyzed with ImageJ (http://rsb.info.nih.gov/ij/). All experiments were done blind with respect to the experimental condition. Spine density was measured on 3D projections and defined as the number of spines per $10 \mu \mathrm{m}$ dendritic length. Spine length was measured as the distance from the outer edge of the dendritic shaft to the tip of the spine. Spine head diameter was estimated as the length of the longest line through the spine head orthogonal to the neck of the spine. Spine morphology was estimated according to the following parameters: mushroom $(\mathrm{M})$, head diameter exceeding $0.5 \mu \mathrm{m}$; thin $(\mathrm{T}), 0.2<$ head $\leq 0.5$ $\mu \mathrm{m}$ in diameter and a maximum length at least twice as large as the head diameter; filopodia-like (F), head $\leq 0.2 \mu \mathrm{m}$ and not clearly distinguishable from the neck; other $(\mathrm{O}), 0.2<$ head $\leq 0.5 \mu \mathrm{m}$ in diameter and a maximum length less than twice the head diameter (Harris et al., 1992; Kim et al., 2008).

Subcellular fractionation and immunoprecipitation from mouse brain. The V1 membrane fraction was prepared from P7 mouse brains by differential centrifugation as previously described (Konecna et al., 2006; Steuble et al., 2010). Washed V1 pellets were resuspended in immunoprecipitation (IP) buffer (PBS, 320 mm sucrose, and 5 mM EDTA, pH 7.4) and stirred for $1 \mathrm{~h}$ at $4^{\circ} \mathrm{C}$. For immunoblotting, $2 \mathrm{mg}$ magnetic Dynabeads M-280 protein A (Invitrogen) was incubated with $10 \mu \mathrm{g}$ IgG for 40 $\mathrm{min}$ and washed four times in IP buffer. V1 inputs were adjusted to $\sim 0.7$ 
A

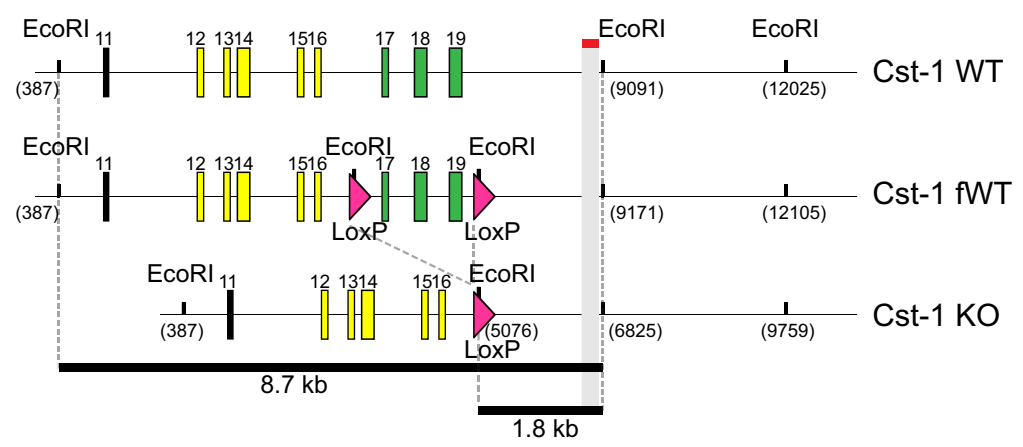

B

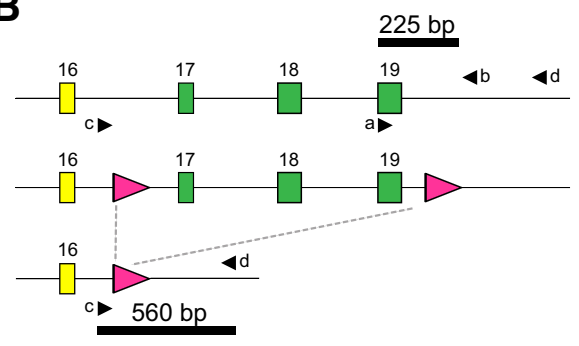

Cst-1 WT

Cst-1 fWT

Cst-1 KO
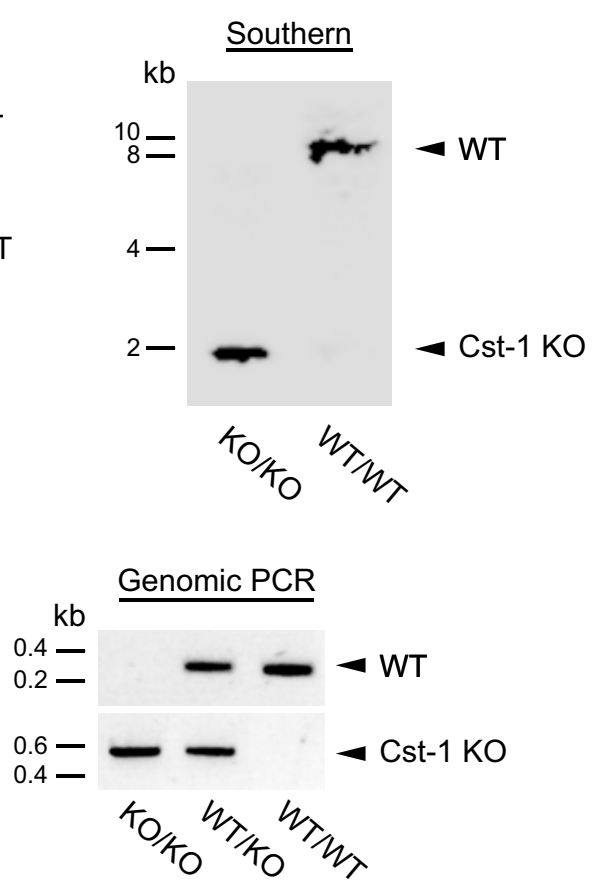
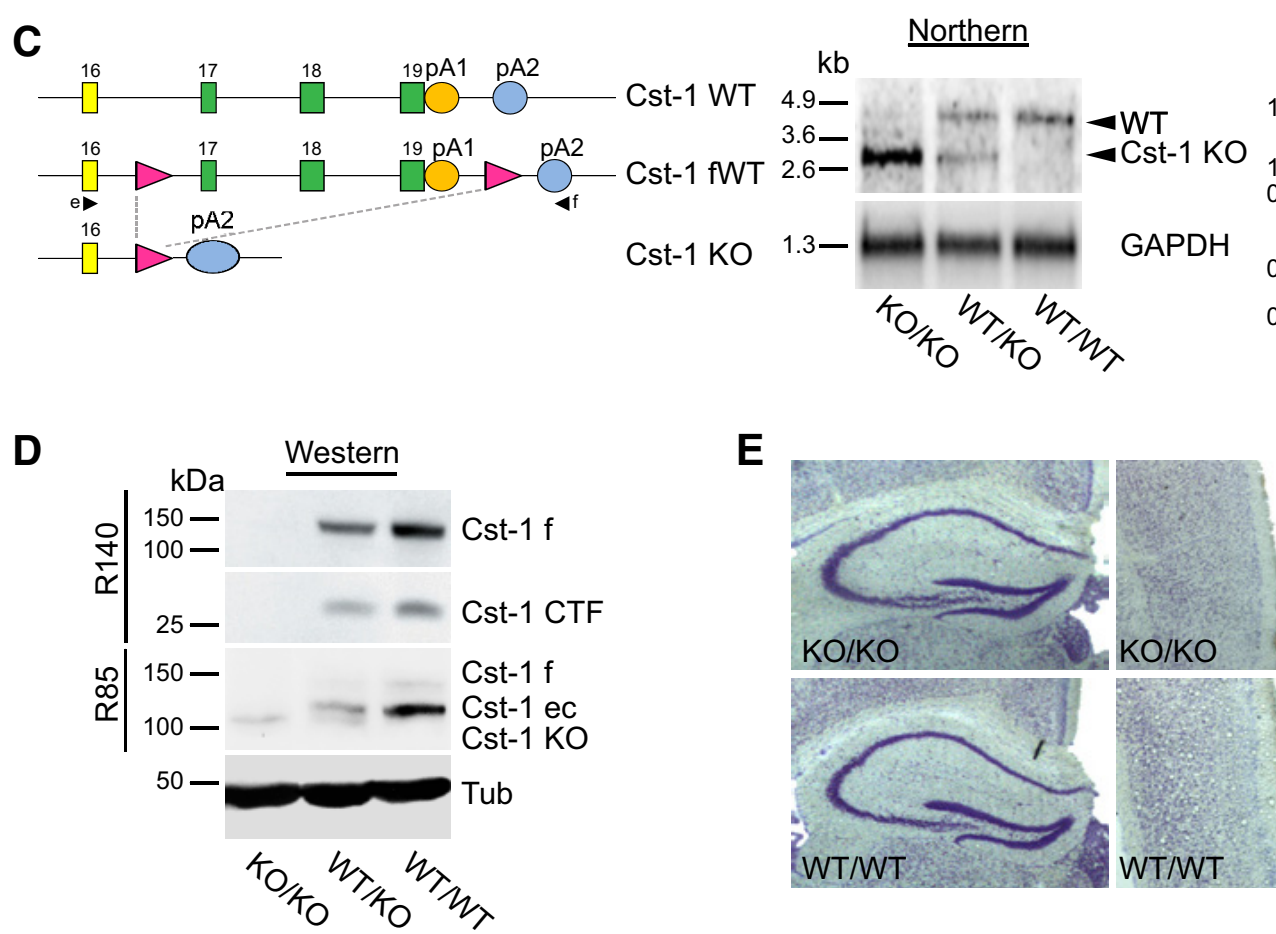

E

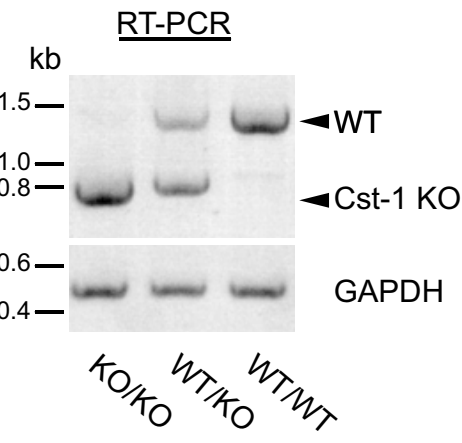

Figure 1. Characterization of a Cst-1 KO mouse. $\boldsymbol{A}$, Left, Schematic representation of the Southern blot analysis of EcoRI-digested genomic DNA with a probe downstream of exon 19 of calsyntenin-1. Right, Southern blot demonstrating the presence of a sole $1.8 \mathrm{~kb}$ fragment in the homozygous Cst-1 K0 mice, whereas WT mice contained the $8.7 \mathrm{~kb}$ fragment. B, Left, Schematic representation of the PCR analysis of genomic DNA as a complement to the Southern blot analysis. Right, PCR with primers a and b, the former located within the floxed segment, resulted in a 225 bp amplicon from the WT allele (right, top). Primers c and d were placed up and downstream, respectively, of the floxed segment and thus resulted in a $560 \mathrm{bp}$ amplicon in the Cst-1 K0 allele (right, bottom). C, Left, Schematic representation of the Northern blot analysis of polyadenylated RNA. Middle, The Northern blot demonstrates the presence of a stable truncated RNA transcript from the Cst-1 K0 allele, indicating that the polyadenylation site is located downstream of the loxP site (pA2; left). Right, RT-PCR with primers e and f, located within exon 16 and at pA2, respectively, confirmed the presence of a Cst-1 KO transcript that is $\sim 0.7 \mathrm{~kb}$ shorter than the WT transcript. $\boldsymbol{D}$, Immunoblots with antibody R140 raised against the cytoplasmic segment of calsyntenin-1 demonstrate the absence of the functionally active full-length transport form of calsyntenin-1 in homozygous Cst- 1 KO mice together with an absence of its CTF. Antibody R85 against the N-terminal cadherin-like domains detected a truncated form of calsyntenin-1 in homozygous and heterozygous Cst-1 K0 mice that is slightly shorter than the ectodomain in WT mice. $\boldsymbol{E}$, Normal gross morphology of homozygous (st-1 KO hippocampus (left) and cortex (right) revealed by Nissl staining. CTF, C-terminal fragment; ec, ectodomain; f, full-length; fWT, floxed wild-type; pA, polyadenylation site; Tub, tubulin. 
$\mathrm{mg} / \mathrm{ml}$ with IP buffer and incubated with beads precoated with the respective immunoprecipitating antibody for $1 \mathrm{~h}$ at $4^{\circ} \mathrm{C}$. Beads with immuno-isolated organelles were washed 10 times with $1 \mathrm{ml}$ IP buffer, once with $20 \mathrm{~mm}$ Tris-HCl, pH 7.4. Immuno-isolated organelles were solubilized under mild detergent conditions ( $50 \mu \mathrm{l} 20 \mathrm{~mm}$ Tris-HCl, $\mathrm{pH} 7.4,0.1 \%(\mathrm{v} / \mathrm{v})$ Triton X-100) for $30 \mathrm{~min}$ at $25^{\circ} \mathrm{C}$. Forty microliters of the respective eluates were resolved together with $10 \mu \mathrm{g}$ V1 input on $4-12 \%$ Bis-Tris gels (Invitrogen). Immunoblotting was performed as described below.

Western blots. At P17, mice were killed by cervical dislocation and hippocampi were quickly dissected, flash frozen in liquid nitrogen, and stored at $-80^{\circ} \mathrm{C}$ before extraction in $300 \mu \mathrm{l}$ of RIPA buffer $(10 \mathrm{~mm}$ Tris- $\mathrm{HCl}, 1 \%$ Nonidet $40,150 \mathrm{~mm} \mathrm{NaCl}, 0.1 \%$ SDS, and $1 \%$ deoxycholate, $\mathrm{pH}$ 7.4) containing protease inhibitors (Complete mini; Roche Diagnostics). The samples were homogenized and kept for $60 \mathrm{~min}$ on ice. After centrifugation for $15 \mathrm{~min}$ at $15,000 \times \mathrm{g}, 4^{\circ} \mathrm{C}$, the supernatant was collected in new Eppendorf tubes. Hippocampal proteins $(20 \mu \mathrm{g})$ were resolved by electrophoresis on a $4-12 \%$ polyacrylamide gel and transferred to nitrocellulose membranes. The nitrocellulose membranes were then incubated in a blocking solution containing 5\% BSA in TBST $0.2 \%$ (Tris-base $0.1 \mathrm{M}$ and $0.2 \%$ Tween $20, \mathrm{pH} 7.4$ ) for $1 \mathrm{~h}$ at room temperature and incubated with primary antibodies overnight at $4^{\circ} \mathrm{C}$. Primary antibodies were rabbit anti-GluN2A (1:1000; Millipore Bioscience Research Reagents, AB1555), rabbit anti-GluN2B (1:500; Millipore Bioscience Research Reagents, AB1557), rabbit anti-GluA1 (1:5000; Millipore, \#05855), mouse anti-PSD95 (1:5000; Millipore, MABN68), rabbit antiGRIP1 (1:500; Sigma-Aldrich, \#AV32496), mouse anti synaptotagmin (1:1000; BD Transduction Laboratories, \# S39520), mouse anti-VAMP2 (1:5000; Synaptic Systems, \#104211), mouse anti-Rab5 (1:100; Santa Cruz Biotechnology, \# sc-46692), rabbit anti-Rab4 (1:200, Santa Cruz Biotechnology, \#sc-28569), mouse anti-Rab11(1:2000; Transduction Laboratories, \#610656), rabbit anti-syntaxin6 (1:1000; Synaptic Systems, \#110062), mouse anti-transferrin receptor (1:1000; Invitrogen, \#1368000), anti-Rip11 (1:2000, provided by Mitsuo Tagaya, Tokyo), mouse anti-N-cadherin (1:2500; Transduction Laboratories, \#C70320), and mouse anti- $\beta$-actin (1:5000; Sigma-Aldrich, \#A5326). After three washes in TBST, a horseradish peroxidase-conjugated anti-rabbit antibody was added to the blots (Pierce Biotechnology). Protein signals were detected by applying SuperSignal West Pico Chemiluminescent Substrate (Pierce) and by exposing the blots in a Stella detector. Protein quantity was measured by densitometry with NIH software and normalized to GAPDH values.

Immunocytochemistry. Primary dissociated hippocampal cultures were prepared from embryonic day 18 mice as described previously (Kaech and Banker, 2006). For immunofluorescence analysis, neurons were fixed in $4 \%$ paraformaldehyde, $4 \%$ sucrose in PBS, pH 7.4, for 10 min, washed, and permeabilized for $1 \mathrm{~h}$ in $10 \% \mathrm{FCS}, 0.1 \%$ glycine, and $0.1 \%$ saponin in PBS. Cells were incubated with primary (polyclonal rabbit antibody R140 was generated against murine calsyntenin-1, monoclonal mouse anti-GluN2A from Millipore Corporation, monoclonal mouse anti-APP from Millipore Bioscience Research Reagents, anti-EEA1 from Santa Cruz Biotechnology, monoclonal mouse anti-transferrin receptor from Invitrogen) in blocking solution and secondary antibodies (Cy3-conjugated and Alexa 488-conjugated antibodies) in blocking solution plus $2 \%$ NGS. Confocal images were acquired with a TCS SP2 AOBS spectral confocal microscope (Leica Microsystems). Images were adjusted only for brightness and contrast using Adobe Photoshop 12.

\section{Results}

\section{Generation and characterization of a Cst-1 KO mouse}

We generated a Cst-1 KO by introducing loxP sites upstream of exon 17 and downstream of exon 19 of the calsyntenin-1 gene to delete the transmembrane and cytosolic segments of calsyntenin-1 (see Materials and Methods). The C-terminal cytosolic segment is essential for vesicular docking to kinesin-1 motors. Immunoblot analysis of whole-brain homogenates from Cst-1 KO mice with R140, an antibody raised against the cytoplasmic segment of calsyntenin-1, demonstrated the absence of the full-length, transportation-competent form of calsyntenin-1, as well as the
Adult Mice

Juvenile Mice

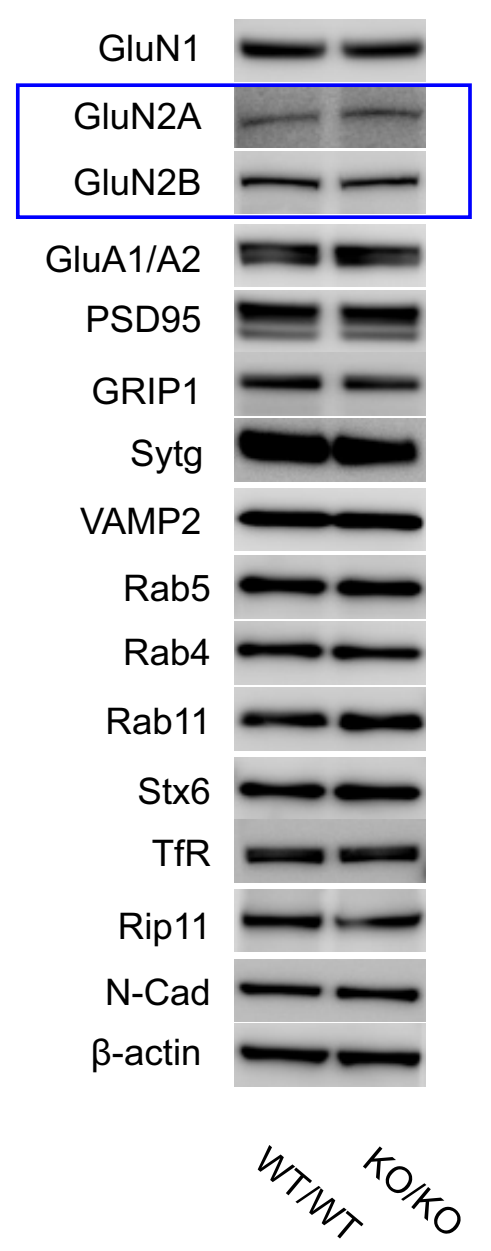

Figure 2. Western blot characterization of the adult and the juvenile Cst-1 K0 mouse. Each $30 \mu \mathrm{g}$ of brain homogenates from WT and (st- $1 \mathrm{KO}$ mice was analyzed by immunoblotting with the indicated antibodies. Sytg, synaptotagmin; Stx6, syntaxin 6; TfR, transferrin receptor; $\mathrm{N}$-Cad, N-cadherin.

C-terminal cytosolic segment (Fig. 1D). As expected for the expression of a truncated mRNA transcript, antibody R85 raised against the $\mathrm{N}$-terminal cadherin-like domains of calsyntenin-1 revealed the presence of truncated calsyntenin- 1 that is slightly shorter than the calsyntenin-1 ectodomain, the predominant form of calsyntenin-1 that accumulates in WT mice after juxtamembrane cleavage in the extracellular compartment. Because of the absence of the transmembrane and cytosolic segment, this fragment lacks the kinesin-docking function of full-length calsyntenin-1. Therefore, it is unlikely that this truncated form of calsyntenin-1 exhibits residual calsyntenin-1-dependent functions for vesicular transport in $\mathrm{KO}$ mice. Moreover, a dominantnegative effect of this truncated calsyntenin-1 can be excluded with high probability, because of its close structural homology to the released ectodomain of calsyntenin-1 found at markedly higher levels in WT mice. Cst-1 KO mice were viable and fertile, without an overt morphological or behavioral phenotype, and their weight was comparable to WT littermates $(\mathrm{P} 17$ : WT $=7.1 \pm 0.39 \mathrm{~g}$, $n=14$; Cst $-1 \mathrm{KO}=6.9 \pm 0.33 \mathrm{~g}, n=14, p>0.6 ; \mathrm{P} 48: \mathrm{WT}=20.6 \pm$ $0.5 \mathrm{~g}, n=31$; Cst $-1 \mathrm{KO}=19.8 \pm 0.8 \mathrm{~g}, n=18, p>0.3)$. Investiga- 
tion of brain sections by in situ hybridization and Nissl staining did not reveal gross morphological alterations (Fig. 1E). Moreover, in adults the absence of calsyntenin-1 did not affect the expression of an extended series of synaptic proteins as shown in Western blots of brain homogenates from WT and Cst-1 KO (Fig. 2). In the juvenile $\mathrm{KO}$ mouse, most synaptic proteins were similarly unchanged (Fig. 2), except for NMDA receptors as described below.

\section{Basal excitatory synaptic transmission} is decreased in juvenile Cst-1 KO mice The preferential localization of calsyntenin-1 in the CA1 area of the hippocampus (Hintsch et al., 2002) in a pattern indicating dendritic expression (Konecna et al., 2006) suggests a function at inputs to CA1 pyramidal cells. Because the expression levels of calsyntenin-1 are highest in juvenile mice, we compared spontaneous EPSCs in acute hippocampal slices prepared at P15-P21 from Cst-1 KO and WT mice. Analysis of recordings from CA1 pyramidal cells (Fig. $3 A$ ) showed that the amplitudes of spontaneous EPSCs were similar in slices prepared from juvenile (P15-P21) WT and Cst-1 KO mice $(\mathrm{WT}=-14.6 \pm 1.1 \mathrm{pA}$, Cst-1 KO $=$ $-15.5 \pm 1 \mathrm{pA}, p>0.05$; Fig. $3 B, C)$. However, spontaneous EPSC frequency was markedly decreased in Cst- $1 \mathrm{KO}$ compared with WT mice $(\mathrm{WT}=0.9 \pm 0.3 \mathrm{~Hz}$, Cst- $1 \mathrm{KO}=0.3 \pm 0.1 \mathrm{~Hz}, p<0.01$; Fig. $3 B, C)$. The input/output curve obtained from field recordings revealed a significant decrease in EPSP slope in Cst-1 KO compared with WT mice (Fig. $3 D, E$ ). To rule out a bias in the placement of the stimulating electrode, the magnitude of the EPSP was replotted as a function of the fiber volley at a constant amplitude of $-0.2 \mathrm{mV}$, which confirmed a decrease in synaptic transmission in the Cst- $1 \mathrm{KO}$ mice $(\mathrm{KO}=-0.11 \pm 0.02$; $\mathrm{WT}=-0.23 \pm 0.03, p<0.05$; Fig. $3 F)$. A reduction in synaptic transmission can reflect either a presynaptic process in which vesicular release is diminished, or a postsynaptic effect in which the number of synapses is reduced or fewer mature or functional synapses are present. To distinguish between these two possibilities we assessed parameters for presynaptic release of neurotransmitter. First we examined paired-pulse facilitation (PPF), which was not significantly different at pulse intervals ranging from 50 to $500 \mathrm{~ms}$ (Fig. 4A,B). Short-term plasticity induced by stimulation with three stimuli at $100 \mathrm{~Hz}$ was also not different in Cst-1 KO compared with WT slices (12-15 min: WT $=106 \pm$ $6 \%$, Cst- $1 \mathrm{KO}=107 \pm 3.3 \%, p>0.1$; Fig. $4 C, D)$. These results indicate that presynaptic release properties are not modified in the hippocampus of Cst-1 KO mice. A further possibility accounting for decreased synaptic transmission could be a decrease in dendritic spine density. However, the number of spines per unit length was not changed in CA1 pyramidal cells from Cst-1 KO compared with WT dendrites (Fig. 4E). decrease in the fEPSP.
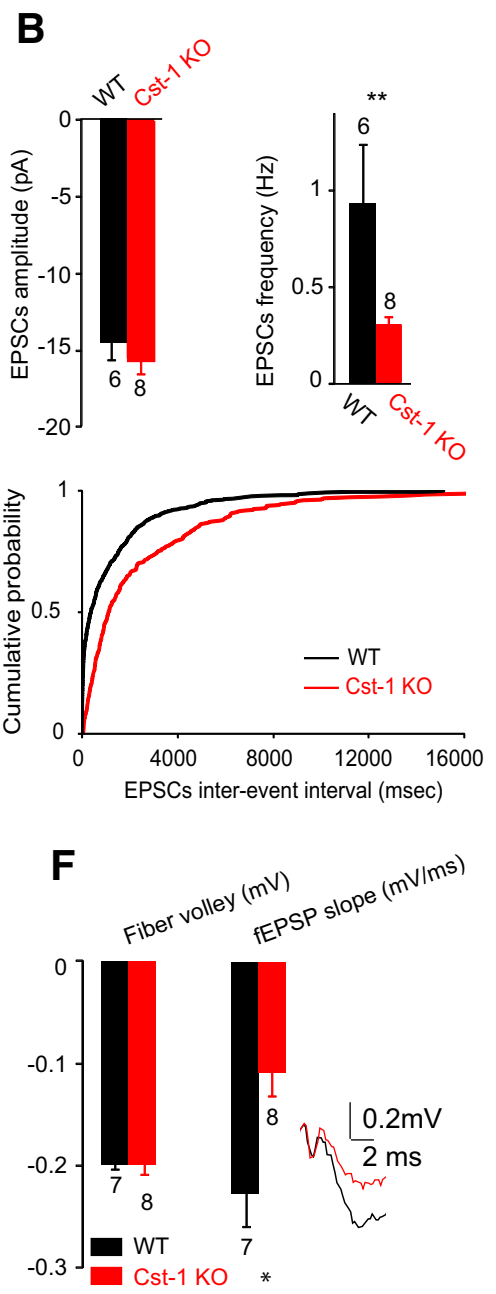

E

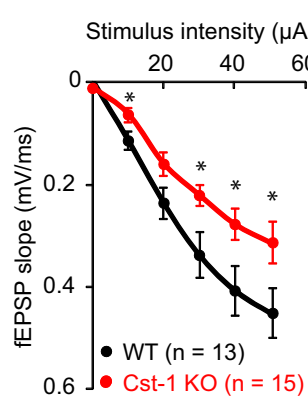

Figure 3. Excitatory synaptic transmission is reduced in juvenile (st-1 KO mice. $A$, The frequency of spontaneous EPSCs recorded in CA1 pyramidal cells voltage clamped at $-70 \mathrm{mV}$ is reduced in Cst-1 K0 versus WT slices in P15-P21 mice. B, Bar graphs showing no significant change in amplitude but a marked decrease in frequency of spontaneous EPSCs in Cst-1 KO mice. from Cst-1 K0 mice. $\boldsymbol{E}$, Input- output relation comparing CA1 field responses in WT and Cst-1 K0 mice $\boldsymbol{F}$, Superimposed traces scaled to the amplitude of the fiber volley. Data normalized to the amplitude of the input volley reveal a significant

\section{Involvement of calsyntenin-1 in dendritic transport}

Further evidence for a postsynaptic mechanism mediating the observed reduction in synaptic transmission was the presence of calsyntenin-1-positive puncta along all dendrites as visualized with R140, an antibody against the cytosolic fragment of calsyntenin-1 (Fig. 5A). A well established function of calsyntenin-1 is as a docking protein that directly binds to the light chain of kinesin-1 for fast axonal transport (Konecna et al., 2006; Steuble et al., 2012; Vagnoni et al., 2012). We therefore checked for a similar role in dendrites. Indeed, the considerable degree of colocalization of dendritic calsyntenin-1 puncta with both the transferrin receptor (TfR), a marker for recycling endosomes, as well as with APP, which is carried in early endosomal calsyntenin-1 vesicles (Steuble et al., 2012), indicates that dendritic calsyntenin-1-associated vesicles are involved in transport of both early and recycling endosomal organelles (Fig. 5A,B). Importantly, dendritic calsyntenin-1 also colocalizes with NMDA receptor subunits (Fig. 5C,D). 
A

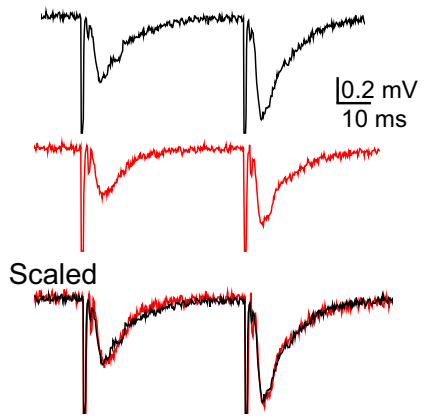

C

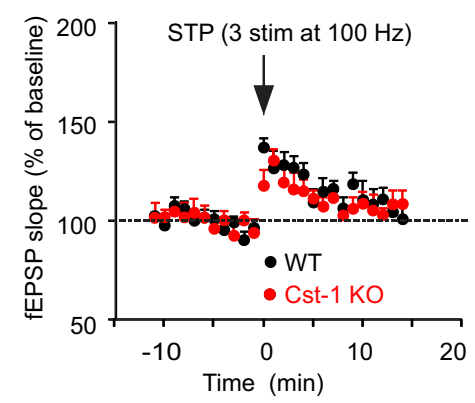

B

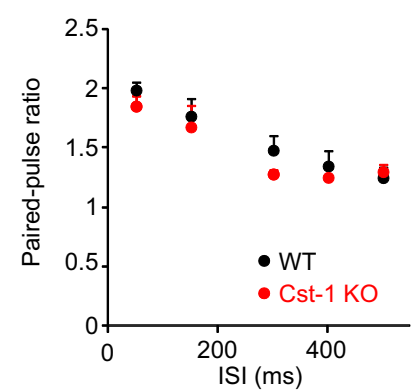

D

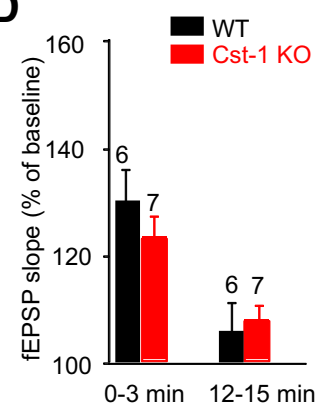

E

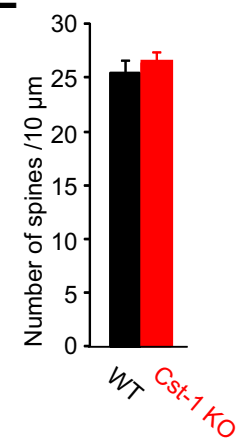

Figure 4. Presynaptic function is not changed in CA1 pyramidal cells from juvenile (st-1 K0 mice. $A$, Field recordings show that PPF at 50 ms is not altered in (st-1 KO mice. B, Pooled data for a range of paired-pulse inter stimulation intervals (ISI). C, Short-term synaptic potentiation is not affected in Cst-1 KO mice. D, Pooled data showing pronounced short-term plasticity during the first 3 min after stimulation, which decrease toward baseline after $15 \mathrm{~min}$. $\boldsymbol{E}$, Dendritic spine density is unchanged in Cst-1 KO mice.

greater GluN2B-mediated component, we compared the effects of a GluN2A subunit antagonist, NVP-AAM $(0.1 \mu \mathrm{M}$; Auberson et al., 2002; Bartlett et al., 2007), and a GluN2B subunit antagonist, Ro256981 (3 $\mu \mathrm{M}$; Fischer et al., 1997) on evoked NMDA EPSCs at $+30 \mathrm{mV}$ in the presence of NBQX $(25 \mu \mathrm{M})$ and picrotoxin (50 $\mu \mathrm{M})$. The GluN2B subunit antagonist induced a greater suppression of EPSCs in Cst-1 KO neurons whereas the GluN2A subunit antagonist was more effective in reducing EPSCs in WT neurons (Fig. 6C). Thus, at Cst-1 KO synapses the proportion of GluN2B subunit-containing receptors was increased $(\mathrm{WT}=20.6 \pm$ 6.9; Cst-1 $\mathrm{KO}=40.6 \pm 3.7$; $p<0.05$; Fig. $6 C)$, whereas the proportion of GluN2Acontaining receptors was decreased $(\mathrm{WT}=68.9 \pm 5.8 ;$ Cst $-1 \mathrm{KO}=44.5 \pm$ 8.2; $p<0.05$; Fig. 6C).

Western blots of whole hippocampi from P17 mice also showed that GluN2B levels are higher in Cst-1 KO compared with WT mice (ratio GluN2B/GAPDH: $\mathrm{WT}=100 \pm 7.1$, Cst $-1 \mathrm{KO}=127.8 \pm 3.4$, $p=0.0246$; Fig. $6 D, E$ ). No difference in total tissue GluN2A levels was observed (ratio GluN2A/GAPDH: WT $=100 \pm$ 9.7, Cst- $1 \mathrm{KO}=107.4 \pm 11.4, p>0.05)$. As calsyntenin-1 is associated with trans-

\section{Enhanced synaptic expression of GluN2B in Cst-1 KO mice} If calsyntenin-1 contributes to dendritic trafficking of proteins, the reduction in excitatory transmission that we observed in the Cst-1 KO mouse may arise from disrupted targeting of glutamatergic receptors. We therefore assessed AMPA and NMDA receptor-mediated responses by comparing their ratios in WT versus Cst-1 CA1 pyramidal cells. Schaffer collaterals were stimulated to evoke EPSCs in CA1 pyramidal cells voltage clamped at $-70 \mathrm{mV}$, where extracellular magnesium (1 mM) blocks most NMDA current, to measure AMPA responses and then at +30 $\mathrm{mV}$, where the NMDA receptor-mediated component is apparent (Fig. 6A). We also took advantage of the much faster decay kinetics of AMPA versus NMDA receptor currents (Fig. 6A, arrows) to calculate the proportion of the current mediated by each receptor channel. Our data show that the AMPA/NMDA response ratio was lower in Cst-1 KO than in WT cells (WT = $-1.2 \pm 0.6$, Cst- $1 \mathrm{KO}=-0.4 \pm 0.2, p<0.05$; Fig. $6 A$ ). Beginning in the second postnatal week, there is a switch from predominantly GluN2B subunit-containing NMDA receptors to increasing expression of GluN2A subunit-containing NMDA receptors (Monyer et al., 1994; Sheng et al., 1994). We therefore examined in greater detail the evoked response mediated by NMDA receptors. Our recordings show that the NMDA component of the current had slower decay kinetics in the Cst-1 KO versus the WT neurons (WT tau $=89 \pm 12 \mathrm{~ms}$, Cst $-1 \mathrm{KO}$ tau $=$ $147 \pm 19 \mathrm{~ms}, p<0.05$; Fig. $6 B$ ), which may reflect a high expression of NMDA receptors containing the GluN2B subunit (Monyer et al., 1994; Vicini et al., 1998; Tovar et al., 2000). In contrast, the decay kinetics of AMPA receptor-mediated EPSC was not modified (WT tau $=19.2 \pm 4.5 \mathrm{~ms}$, Cst- $1 \mathrm{KO}$ tau $=$ $15.4 \pm 2.4 \mathrm{~ms}, p>0.3$; Fig. $6 B$ ). To determine whether the slower NMDA receptor kinetics in the Cst- $1 \mathrm{KO}$ was indeed due to a port vesicles, we were interested in whether these vesicles may contain NMDA receptors. Calsyntenin-1-positive endosomes were immuno-isolated from whole brains of juvenile mice using the R140 antibody against the cytosolic segment of calsyntenin-1. Western blots revealed the presence of the GluN1 subunit as well as both of the main hippocampal subtypes of the GluN2 subunit, GluN2A and GluN2B in calsyntenin-1 vesicles, which correspond to early and recycling endosomes on the basis of the markers Stx13, TfR, and Rab11 (Fig. 6F). Thus, the above results are consistent with a role for calsyntenin-1 as a transporter of NMDA receptor subunits to dendritic targets.

\section{NMDA receptor-dependent LTP is increased in juvenile Cst-1 KO mice}

As GluN2A and GluN2B subunit-containing NMDA receptors play distinct roles in LTP (Shipton and Paulsen, 2014), we examined whether the increase in GluN2B in Cst-1 KO mice affects synaptic plasticity. We found that LTP induced at Schaffer collateral-CA1 pyramidal cell synapses by HFS with one train or three trains at $100 \mathrm{~Hz}$ was significantly increased in slices from Cst-1 $\mathrm{KO}$ mice $(1 \times 100 \mathrm{~Hz}$ : WT $=139.3 \pm 10.9 \%$, Cst- $1 \mathrm{KO}=172 \pm$ $7.4 \%, p<0.05 ; 3 \times 100 \mathrm{~Hz}: \mathrm{WT}=142.4 \pm 14.7 \%$, Cst $-1 \mathrm{KO}=$ $178.9 \pm 8.5 \%, p<0.05$; Fig. $7 A, E)$. This form of LTP is NMDA receptor dependent as it was blocked by the specific antagonist D-AP5 $(50 \mu \mathrm{M})$ : WT control $=142.4 \pm 14.7 \%$, WT D-AP5 $=$ $107.2 \pm 6.3 \%, p<0.05$. We also induced LTP with a TBS, which has been proposed as a more physiological protocol to study synaptic plasticity (Staubli and Lynch, 1987). Again, LTP induced by TBS was enhanced in Cst- $1 \mathrm{KO}$ compared with WT mice (TBS: $\mathrm{WT}=126.4 \pm 13.5 \%$, Cst $-1 \mathrm{KO}=162 \pm 7.7 \%, p<0.05$; Fig. $7 B, E)$. Moreover, PPF did not change after LTP induction, both in WT and in Cst-1 KO slices (Fig. $7 F$ ). Although in the hip- 
pocampus calsyntenin-1 is expressed most highly in CA1 pyramidal cells, it is also present in CA3 pyramidal cells (Hintsch et al., 2002). However, when we compared LTP induced by HFS $(1 \times 100$ $\mathrm{Hz}$ ) in Cst-1 KO and WT mice at synapses from commissural/associational fibers onto CA3 pyramidal cells, we observed no significant difference $(\mathrm{WT}=150 \pm 10 \%$, $n=7$, Cst $-1 \mathrm{KO}=167.1 \pm 12.7 \%, n=5$, $p>0.05)$.

We also checked whether LTD might be modulated by calsyntenin-1. However, LTD at Schaffer collateral- CA1 pyramidal cell synapses induced by LFS ( $1 \mathrm{~Hz}$ for $15 \mathrm{~min}$ ) was not different in Cst-1 KO versus WT slices $(\mathrm{WT}=88 \pm 5.8 \%, n=4$, Cst- $1 \mathrm{KO}=80.7 \pm 3.9 \%, n=5, p>$ 0.5).Together, these results show that LTP is enhanced in the hippocampus of juvenile Cst-1 KO mice at Schaffer collateralCA1 pyramidal cell synapses.

To determine whether the altered expression of NMDA receptor subunits at Schaffer collateral synapses onto CA1 pyramidal cells is responsible for the enhanced LTP in Cst-1 KO mice, we tested the effects of blocking GluN2A and GluN2B subunits. Neither NVP-AAM $(0.1 \mu \mathrm{M})$ nor Ro25-6981 (3 $\mu \mathrm{M})$ had an effect on baseline synaptic transmission. In the presence of the GluN2B antagonist, the enhancement of LTP (induced by $\mathrm{HFS}, 1 \times 100 \mathrm{~Hz}$ ) was prevented in the Cst-1 KO mouse. LTP attained similar levels in both WT and Cst-1 KO (WT Ro25-6981 = $139.6 \pm 20 \%$, Cst-1 KO Ro25-6981 = $137.8 \pm$ $9.4 \%, p>0.5$; Fig. $7 C, G$ ). In contrast, the enhancement of LTP in the Cst-1 KO mouse was maintained with application of the GluN2A antagonist (WT NVP-AAM = 134.9 $\pm 8.1 \%$; Cst-1 KO $\mathrm{NVP}-\mathrm{AAM}=168 \pm 12 \%, p<0.05$; Fig. $7 D, G)$.

\section{Morphological alterations in CA1 pyramidal cells in Cst-1 KO mice}

The observed changes in synaptic properties correspond to a delay in the maturation of CA1 pyramidal cells in Cst-1 KO mice. As functional modifications are usually associated with structural changes, we examined reconstructions of CA1 pyramidal cells filled with biocytin during electrophysiological recordings from juvenile Cst-1 KO mice. Images were rendered as Neurolucida drawings from confocal imaging stacks. The dendritic tree exhibited reduced complexity in Cst-1 KO neurons (Fig. 8A) reflected as a reduction in dendritic intersections close to the cell body, which was quantified using Sholl analysis (Fig. 8B). As synapses mature, changes in receptor subtype expression occur in parallel with remodeling of dendritic spines. We therefore compared dendritic spines in juvenile Cst-1 KO versus WT mice to look for structural changes that might correspond to our functional data. The density of dendritic spines was analyzed and quantified using confocal microscopy. In hippocampal slices prepared at P17, CA1 pyramidal cells in the Cst-1 KO mice had fewer thin spines $(\mathrm{WT}=45.7 \pm 2 \%$, Cst $-1 \mathrm{KO}=36.9 \pm 3 \%, p=0.0251)$ and more filopodia-like structures $(\mathrm{WT}=6.2 \pm 1 \%$, Cst- $1 \mathrm{KO}=15 \pm 3 \%$, $p<0.01$; Fig. $8 C, D)$. The proportion of mushroom-shaped spines was unchanged. Thus, the more immature state of the dendritic tree, characterized by fewer thin spines and more filopodia (Matus, 2000), may explain the lower frequency of spontaneous EPSCs observed in juvenile Cst-1 KO mice. Furthermore, smaller spines are known to exhibit a greater potential to undergo LTP (Matsuzaki et al., 2004).

\section{Recovery of synaptic function and structure in adult Cst-1 KO mice}

As calsyntenin-1 expresses peak expression shortly after birth and is important in kinesin-1-dependent fast transport of vesicular proteins, it is possible that with time other transport mechanisms can compensate for the absence of calsyntenin-1. Indeed, we found no differences in synaptic function or structure between adult Cst-1 KO and WT mice. In 2-month-old mice, basal synaptic transmission was not significantly altered as shown in recordings of spontaneous EPSC amplitude (WT $=-13.5 \pm 2 \mathrm{pA}$, Cst-1 KO $=-15.9 \pm 1 \mathrm{pA}, p=0.31)$ and frequency $(\mathrm{WT}=$ $0.78 \pm 0.1 \mathrm{~Hz}$, Cst-1 KO=0.9 $\pm 0.2 \mathrm{~Hz}, p=0.72$; Fig. $9 A)$. In addition, LTP (HFS) was not significantly changed (WT = $146.8 \pm 12.1 \%$, Cst $-1 \mathrm{KO}=167.4 \pm 13.7 \%, p>0.05$; Fig. $9 B$ ). Finally, the changes in the structure of the spines (Fig. 9C) and the dendritic tree (Fig. 9D) were no longer observed in adult Cst-1 KO neurons. Thus, the recovery of synaptic properties in adult Cst-1 KO mice is accompanied by a parallel maturation of dendrites. 
A

WT
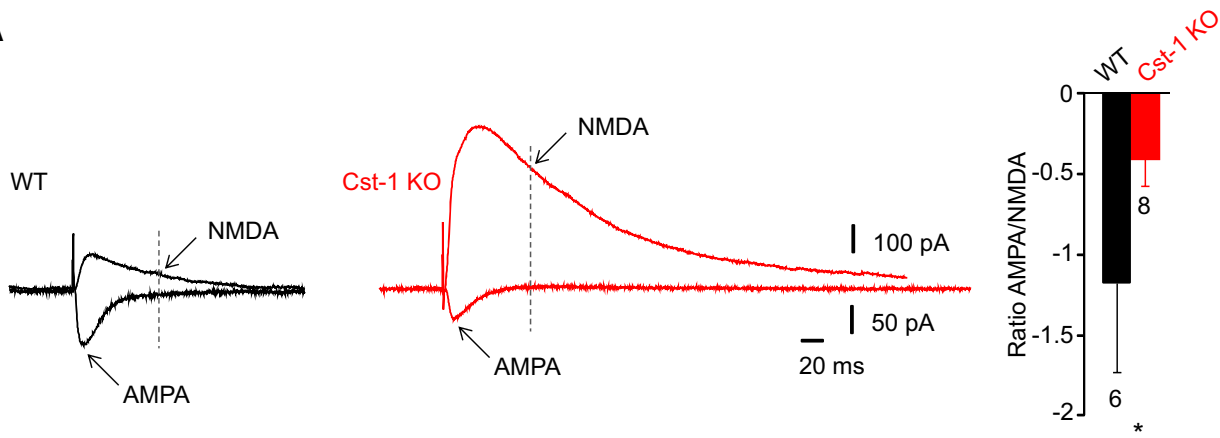

B
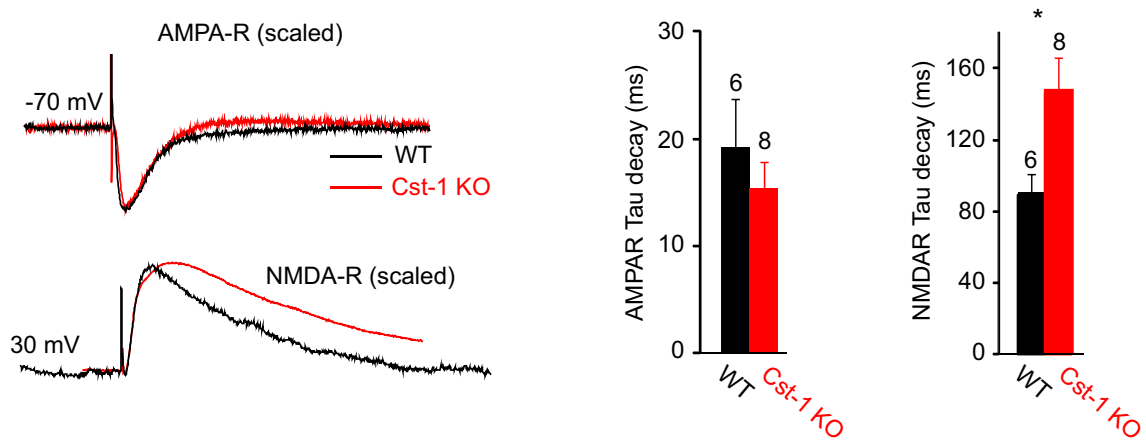

C
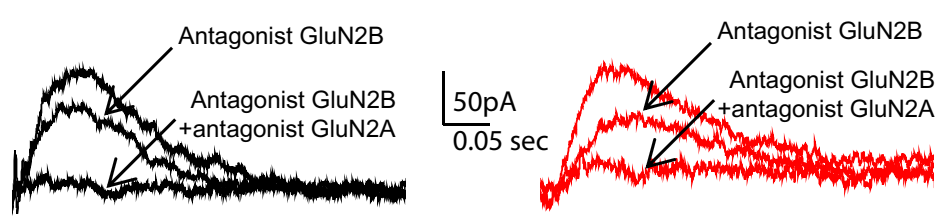

D

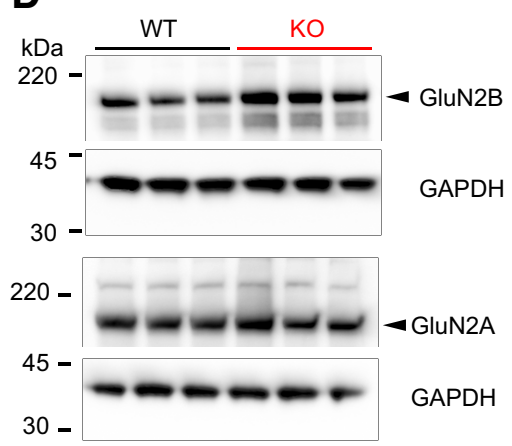

E

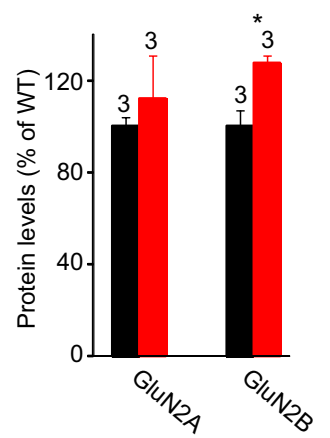

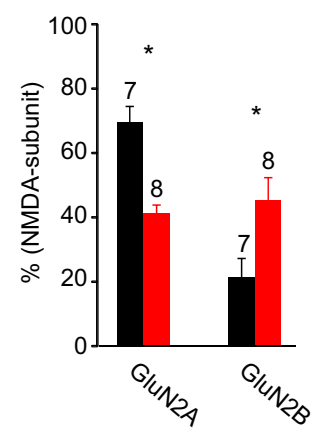

$\mathbf{F}$

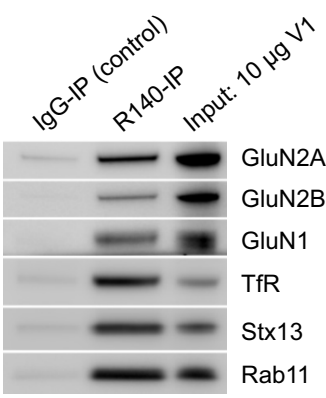

Figure 6. Levels of GluN2B subunit-containing NMDA receptors are increased in juvenile Cst-1 KO mice. A, Representative averaged traces of evoked AMPA and NMDA receptormediated responses recorded in the same CA1 pyramidal cell at $-70 \mathrm{mV}$ (inward currents) and at $+30 \mathrm{mV}$ (outward currents) from a WT and (st- 1 KO mouse. Note that traces are aligned horizontally. Histograms for the ratio of the AMPA to NMDA receptor-mediated response. To minimize the contribution from AMPA receptors, the NMDA receptor-mediated current was measured $80 \mathrm{~ms}$ after stimulation. $\boldsymbol{B}$, Scaling of traces reveals a slowing in the decay kinetics of the NMDA but not the AMPA receptor-mediated responses in Cst- $1 \mathrm{~K} 0$ mice. Histograms show pooled data. C, Pharmacologically isolated NMDA EPSCs exposed to NMDA receptor subunit-specific antagonists shows control current, current remaining after application of an GluN2B subunit antagonist (Ro25-6981; $3 \mu \mathrm{M}$ ) and residual current in the presence of antagonists for both GluN2A (NVP-AAM; $0.1 \mu \mathrm{M}$ ) and GluN2B (Ro25-6981) subunits. Histograms show pooled data. D, Protein levels for GluN2B and for GluN2A quantified by determining the ratio of GluN2B/GAPDH and GluN2A/GAPDH in hippocampal tissue extracts. E, Quantification shows a significant increase in GluN2B but not GluN2A. F, Western blots of recycling endosomes, identified by Rab11 co-IP, from whole brains of WT juvenile mice ( $n=3)$. Note the strong co-IP for NMDA receptors in the R140-enriched fraction, a marker for calsyntenin-1-positive recycling endosomes. Recycling endosomes are also positive for syntaxin-13 (Stx13), a general marker for endosomes. 
A

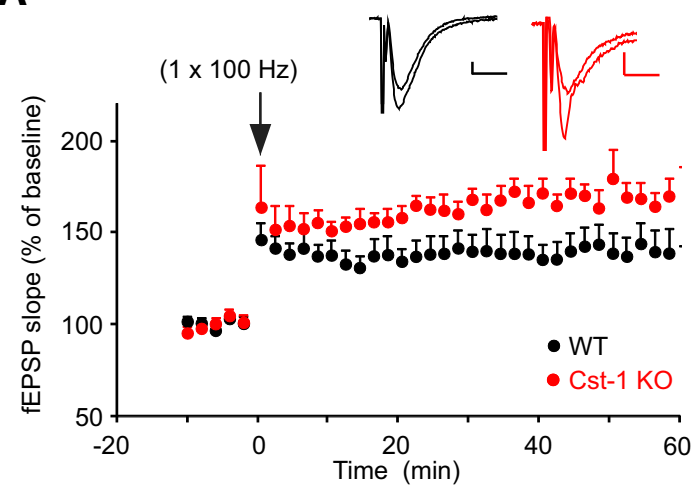

C

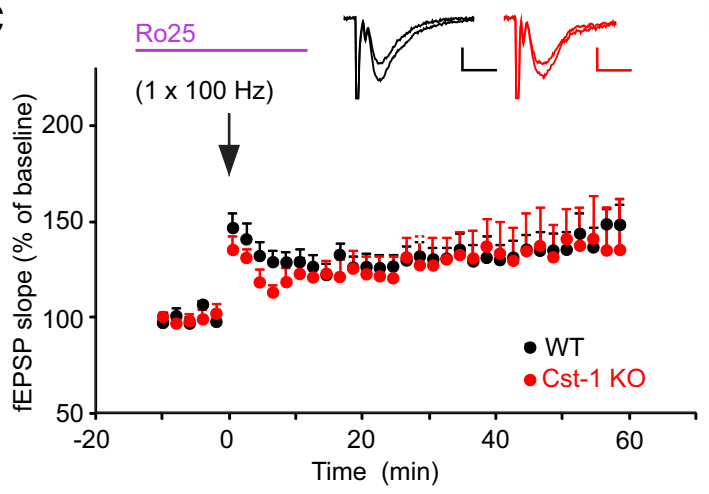

B
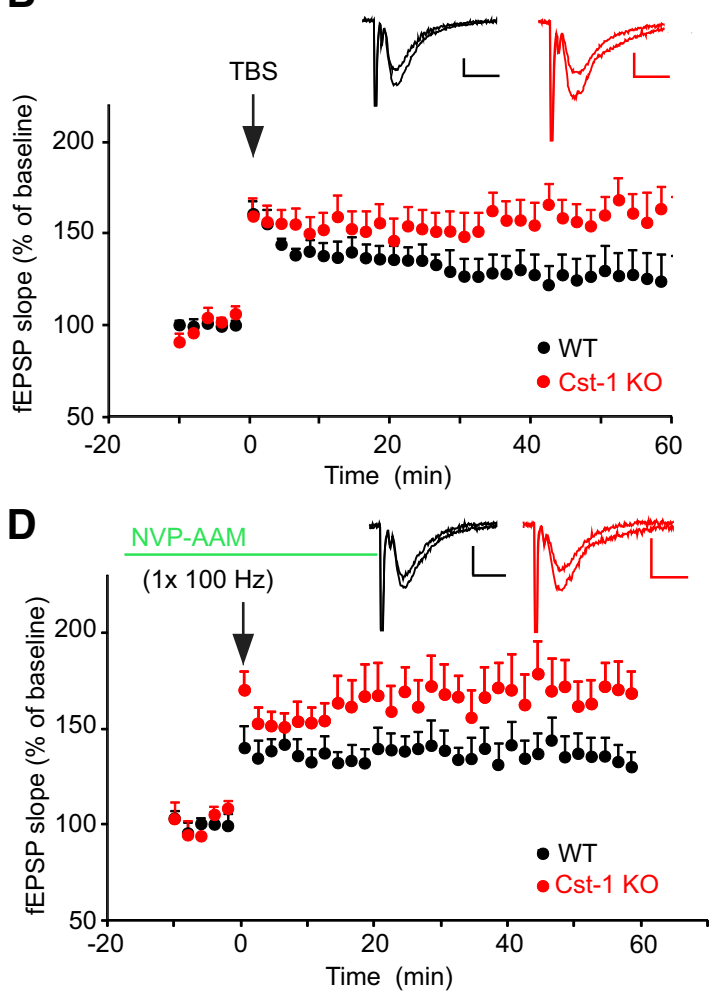

E

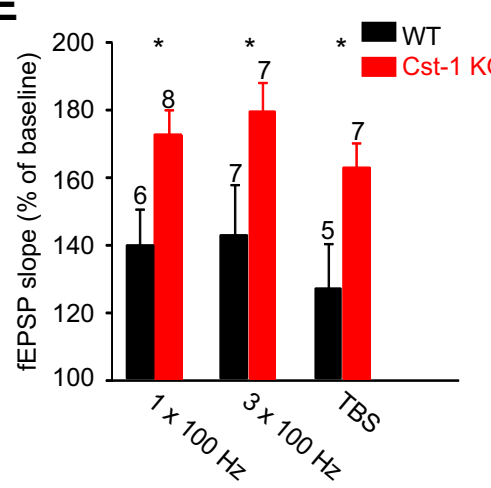

$\mathbf{F}$

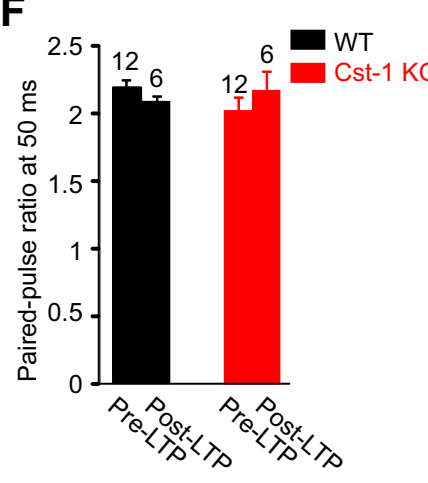

G

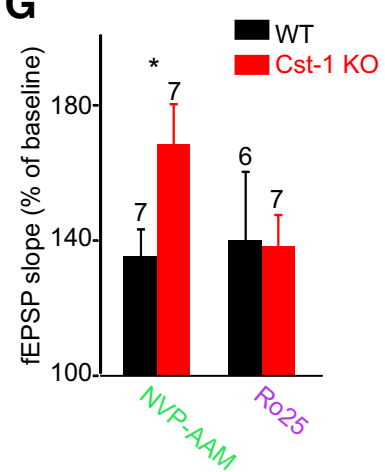

Figure 7. Enhanced NMDA receptor-dependent LTP at Schaffer collateral-CA1 pyramidal cell synapses in juvenile Cst-1 K0 mice. $A$, LTP in CA1 pyramidal cells elicited by HFS (100 Hz) of Schaffer collaterals is greater in Cst-1 K0 than in WT mice. Insets are sample traces (averages of 6 sweeps) taken at baseline and at 55- 60 min after induction of LTP. Calibration: $10 \mathrm{~ms}, 0.2 \mathrm{mV}$. B, A similar enhancement is observed for LTP induced by TBS. C, The enhancement of LTP in Cst-1 K0 mice is prevented in the presence of Ro25-6981 (3 $\mu \mathrm{m}$ ), an antagonist for GluN2B subunit-containing NMDARs. $\boldsymbol{D}$, In contrast, the increased LTP in (St-1 KO versus WT mice persists after blocking GluN2A subunit-containing NMDA receptors with NVP-AAM (0.1 $\mu \mathrm{M}) . \boldsymbol{E}$, Pooled data showing enhanced LTP in Cst-1 K0 mice with three different induction protocols. $F$, Paired-pulse analysis indicating that presynaptic release properties are not altered after LTP. G, Pooled data implicating GluN2B subunit-containing NMDA receptors in the enhancement of LTP observed in Cst- $1 \mathrm{KO}$ mice. Histograms for LTP values are averages of data points from 50 to $60 \mathrm{~min}$.

\section{Discussion}

In the absence of calsyntenin-1, we observed a disruption in the ratio of GluN2B subunit to GluN2A subunit-containing NMDA receptors expressed at the Schaffer collateral-CA1 pyramidal cell synapse in the juvenile mouse. As a consequence, synaptic function was altered in association with structural modifications of the dendritic tree and dendritic spines. These changes are consistent with calsyntenin-1's role in vesicular trafficking.

Calsyntenin-1 is a docking protein that couples vesicles to kinesin-1 for fast transport along microtubules (Konecna et al., 2006). It is present in the trans-Golgi network where calsyntenin1-positive organelles are part of the system of endosomal pathways (Ludwig et al., 2009; Steuble et al., 2010). Calsyntenin-1 vesicles are always found on plus end-directed trajectories, a characteristic of replenishment vesicles that carry components required for distal neuronal functions. Furthermore, calsyntenin-1directed traffic is one way and centrifugal, as it is subject to proteolytic cleavage when the vesicles reach their distal destination (Steuble et al., 2010, 2012). Because it acts as a docking protein for distinct types of endosomal vesicles, a direct role of calsyntenin-1 in the process of cargo selection is unlikely. We therefore assume that calsyntenin-1 vesicles generated in the trans-Golgi network are loaded with both the GluN2A and the GluN2B subunits and delivered to the trans-Golgi network without preference, consistent with our coimmunoprecipitation data (Fig. $6 F$ ). However, the peak expression of calsyntenin-1 overlaps with the time window for a key postnatal switch in the expression of NMDA receptors with distinct subunit composition. The GluN2B subunit- 
A

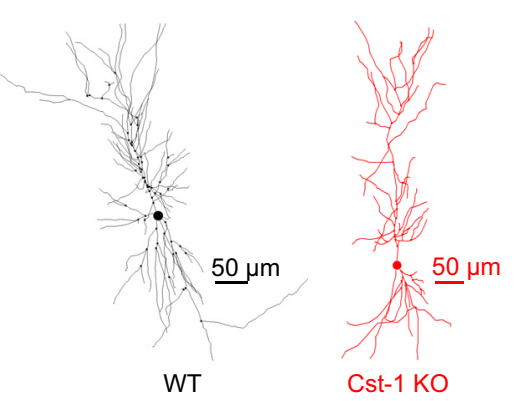

B

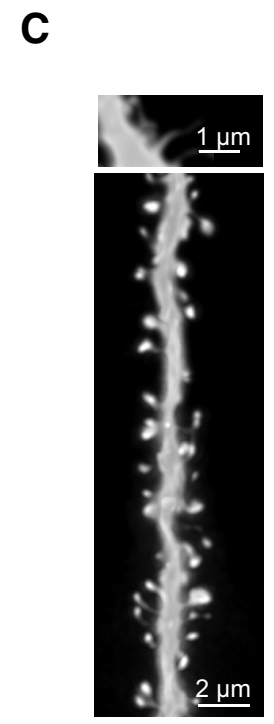

WT

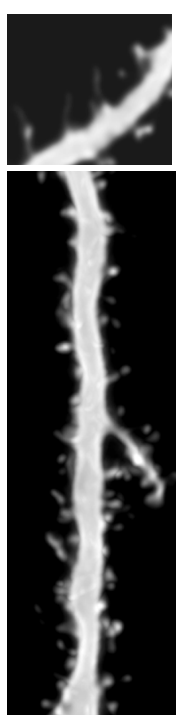

Cst-1 KO
D
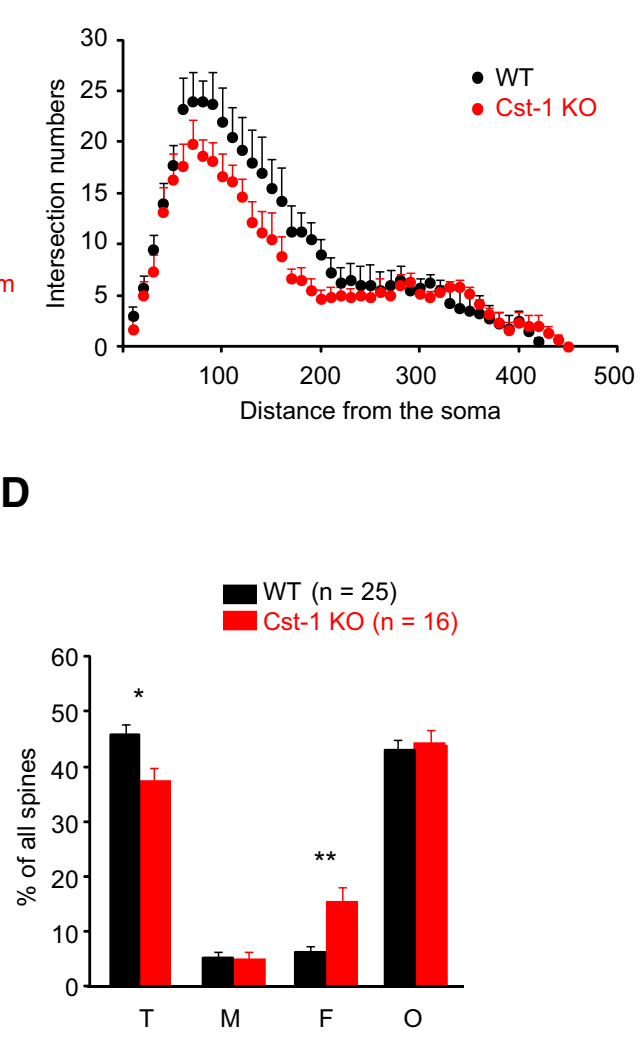

Figure 8. The spine-type distribution is altered in CA1 pyramidal cells from juvenile CSt-1 KO mice. $\boldsymbol{A}$, Neurolucida reconstructions revealing decreased branching in the proximal dendritictree of a $\mathrm{CA} 1$ pyramidal cell from a Cst-1 $\mathrm{K} 0$ mouse. $\boldsymbol{B}$, Sholl analysis comparing data from five WT and six Cst-1 K0 mice. C, Dendritic segments of biocytin-filled CA1 pyramidal cells from a WT and a CSt-1 K0 mice. Higher magnification insets provide examples of filopodial spines. $D$, Proportions of thin $(T)$, mushroom (M), filopodia-like $(F)$, and other $(0)$ spines showing fewer thin spines but more filopodial structures in Cst-1 KO compared with WT dendrites.

containing NMDA receptors prevail early during development whereas levels of the GluN2A subunit-containing NMDA receptor begin to rise in the second postnatal week. The switch from GluN2B to GluN2A subunits is initiated at the transcriptional level by the increased synthesis of mRNA encoding GluN2A subunits at the expense of mRNA encoding GluN2B subunits. After translation in the endoplasmic reticulum, the new GluN2A subunits need to be transported to their synaptic destination through the Golgi complex and along the dendrites. Based on its essential role for fast, microtubule-dependent transport of vesicular cargo from the Golgi complex to the dendrites, calsyntenin-1 allows for the rapid implementation of the switch from GluN2B to GluN2A subunits at the synaptic level. Without calsyntenin-1 the transcriptionally controlled switch from the production of GluN2B to GluN2A subunits is not faithfully reflected in a timely manner at synapses. As a result, synapses of young Cst-1 KO mice exhibit increased levels of GluN2B subunits, the default subunit in early development. Conversely, for dendritically transported proteins that do not undergo a developmental switch, such as AMPA receptors, we found no evidence for changes in synaptic expression (Fig. $4 A, B$ ). As calsyntenin-1 is also expressed before the NMDA receptor subunit switch occurs, one might expect additional deficits that impact GluN2B trafficking. However, the GluN2B KO mouse is neonatally lethal (Kutsuwada et al., 1996), suggesting that additional mechanisms must be present to traffic these subunits. Indeed, KIF17, which is also a kinesin motor protein, is one example of a protein critical for the specific transport of GluN2B to the synapse (Yin et al., 2011). In the adult, we no longer observed a difference in synaptic function between Cst-1 $\mathrm{KO}$ and WT mice. The fact that the GluN2A subunit is not required for survival may explain the lack of an additional fast transport system for this subunit. Thus, without calsyntenin-1, GluN2A and GluN2B subunit-containing NMDA receptors still reach their synaptic destination via other calsyntenin-negative transport vesicles, albeit with a delay and possibly with some losses due to partially incorrect targeting.

Our data point to a postsynaptic site of action for calsyntenin-1 in its regulation of synaptic function. Accordingly, colocalization experiments showed that calsyntenin-1, as well as NMDA receptor subunits, are present in dendrites (Fig. 5). Moreover, in the absence of calsyntenin-1, postsynaptic AMPA/NMDA receptor ratios were altered as was the expression of NMDA receptor subtypes. NMDA receptor-dependent LTP, which is considered to involve mainly postsynaptic mechanisms, was enhanced. The delay in maturation of functional synaptic properties was also accompanied by structural changes in the postsynaptic elements. The dendritic spines exhibited altered profiles and the dendritic arborization was less developed. In contrast, presynaptic release properties were not affected in the Cst-1 KO mouse. In this respect it is of interest that the differentiation of presynaptic terminals also does not depend on calsyntenin-1, but rather requires calsyntenin-3 (Pettem et al., 2013). Furthermore, this study showed that calsyntenin-3, which has much lower affinity for kinesin-1 than calsyntenin-1, is essential for synapse development through its interaction with $\alpha$-neurexin.

Surprisingly, deletion of calsyntenin-1 resulted in one of the very few known examples where lack of a synaptic protein enhances LTP. As reported previously, GluN2B-containing NMDA receptors mediate EPSCs with greater amplitude and duration compared withGluN2A-containing receptors (Monyer et al., 1994; Vicini et al., 1998; Tovar et al., 2000; Barria and Malinow, 2002). Two distinct mechanisms may account for the enhanced LTP mediated by GluN2B subunit-containing NMDA receptors. First, the slower kinetics of GluN2B-mediated EPSPs allows more calcium influx, and significantly enhances LTP, as shown previously in studies in the CA1 region of the hippocampus in juvenile animals (Ito et al., 1996; Köhr et al., 2003). This process depends on a high-affinity interaction between CaMKII and the C-terminal segment of the GluN2B subunit, whereas native GluN2A does not bind to CaMKII (Barria and Malinow, 2005). Preventing this switch from GluN2B to GluN2A subunit-containing NMDA receptors leads to excessive spine motility and synaptogenesis (Gambrill and Barria, 2011). Sec- 
ond, a high expression of GluN2B subunitcontaining NMDA receptors delays the maturation of synapses (Gray et al., 2011). A greater proportion of weak or immature synapses correlates strongly with a greater capacity for LTP (Debanne et al., 1999; Montgomery et al., 2001). The alterations in dendritic spine morphology in Cst-1 KO mice also support an increased ability to undergo plasticity. Spine morphogenesis during development proceeds from filopodia to mature spines, as has been shown in CA1 pyramidal cells (Ziv and Smith, 1996; Fiala et al., 1998), and smaller spines exhibit an inherently greater propensity for LTP (Matsuzaki et al., 2004).

NMDA receptors are important not only for the induction of LTP, but also for certain forms of LTD (Dudek and Bear, 1992). However, we found no difference in NMDA receptor-dependent LTD in Cst-1 KO compared with WT mice, which is in agreement with the finding that NMDA receptors containing the GluN2B unit are not implicated in LTD in juvenile animals (Bartlett et al., 2007).

Together, our results indicate that altered synaptic properties in juvenile Cst$1-\mathrm{KO}$ mice lead to the persistence of a developmentally immature neuronal circuitry with increased synaptic plasticity and malleability. This developmental delay in normal CA1 pyramidal cell function recovers in the adult mouse. This finding underlines the importance of the coordination between the transcriptional switch in NMDA receptor subunit production and the calsyntenin-1-dependent transport mechanism that ensures the appropriately timed expression of receptor subtypes at the synapse. The transient perturbation of signaling in a restricted domain may have long-term consequences in other areas of the brain that depend on hippocampal input. Numerous studies have shown that disruption of synaptic maturation and circuit formation can contribute to the pathogenesis of neurodevelopmental disorders (Kasai et al., 2010; Lai and Ip, 2013). Of particular relevance to our investigation is a recent study showing that the NLR3 ${ }^{\text {R451C }}$ mutation in neuroligin-3, which is linked to autism spectrum disorder (Laumonnier et al., 2004), induces an enhancement in LTP mediated by excessive GluN2B expression (Etherton et al., 2011) similar to what we observe in Cst-1 KO mice. Thus, impairment in the switch of predominantly GluN2B-containing to GluN2A-containing NMDA receptors during the early postnatal period may represent a common mechanism contributing to brain disorders associated with developmental pathologies.
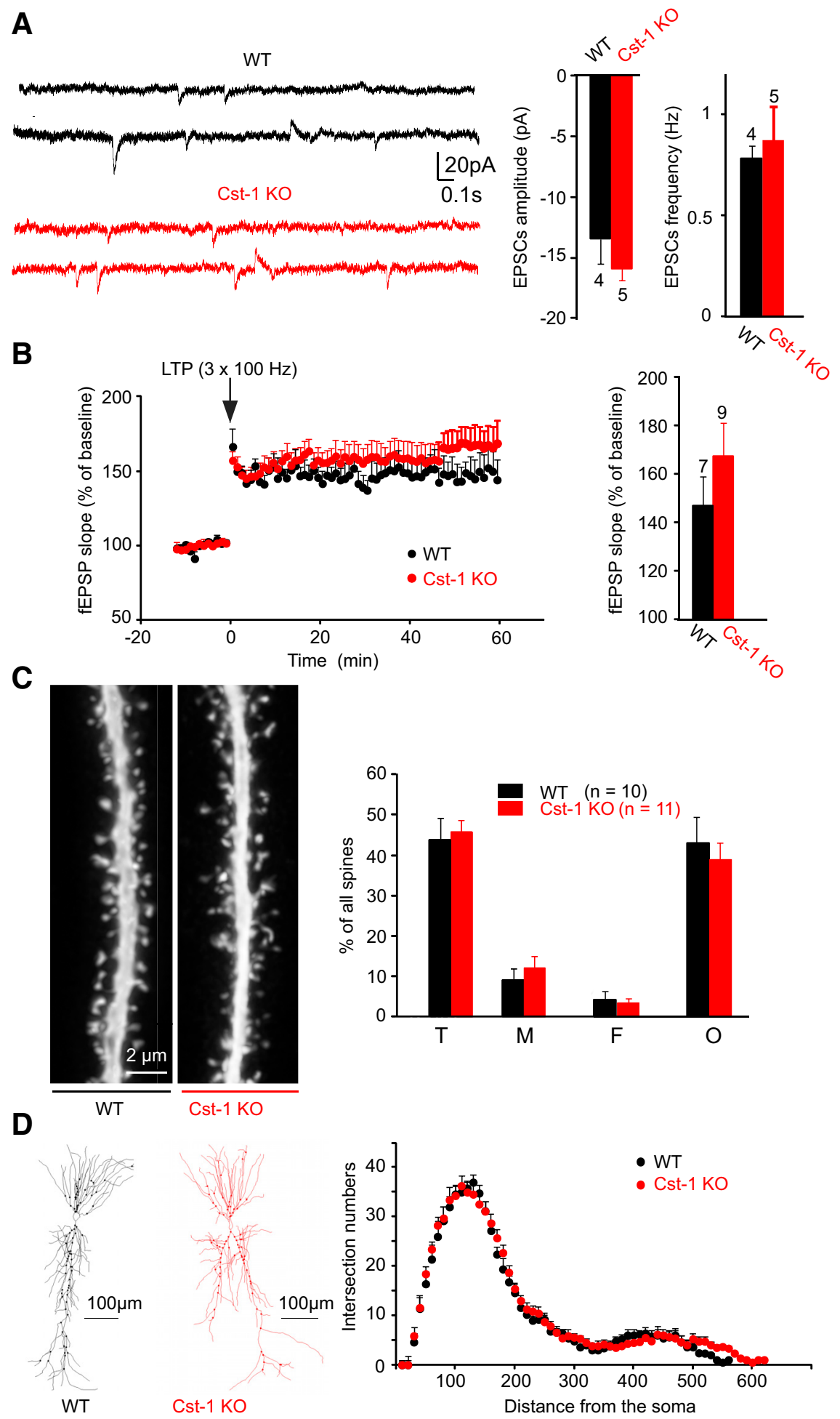

Figure 9. In adult Cst-1 K0 mice, LTP, synaptic transmission, and dendritic morphology of CA1 pyramidal cells are comparable to WT mice. A, Field recordings reveal unchanged LTP ( 3 trains; $100 \mathrm{~Hz}$ ) in adult CSt- $1 \mathrm{KO}$ at Schaffer collateral-CA1 pyramidal cell synapses. $\boldsymbol{B}$, Histograms show no difference in amplitude and frequency of spontaneous EPSCs in adult WT and Cst- 1 KO cells. $\boldsymbol{C}$, Distribution of spine types in dendritic segments from biocytin-filled CA1 pyramidal cells from adult WT and adult Cst-1 K0 slices are not significantly different. Thin (T), mushroom (M), filopodia-like (F), and other (0) spines. $\boldsymbol{D}$, Confocal images of dendritic segments from adult WT and Cst-1 KO mice illustrating identical spine density and morphology.

\section{References}

Araki Y, Kawano T, Taru H, Saito Y, Wada S, Miyamoto K, Kobayashi H, Ishikawa HO, Ohsugi Y, Yamamoto T, Matsuno K, Kinjo M, Suzuki T (2007) The novel cargo Alcadein induces vesicle association of kinesin-1 motor components and activates axonal transport. EMBO J 26:1475-1486. CrossRef Medline 
Auberson YP, Allgeier H, Bischoff S, Lingenhoehl K, Moretti R, Schmutz M (2002) 5-Phosphonomethylquinoxalinediones as competitive NMDA receptor antagonists with a preference for the human $1 \mathrm{~A} / 2 \mathrm{~A}$, rather than $1 \mathrm{~A} / 2 \mathrm{~B}$ receptor composition. Bioorg Med Chem Lett 12:1099-1102. CrossRef Medline

Barria A, Malinow R (2002) Subunit-specific NMDA receptor trafficking to synapses. Neuron 35:345-353. CrossRef Medline

Barria A, Malinow R (2005) NMDA receptor subunit composition controls synaptic plasticity by regulating binding to CaMKII. Neuron 48:289-301. CrossRef Medline

Bartlett TE, Bannister NJ, Collett VJ, Dargan SL, Massey PV, Bortolotto ZA, Fitzjohn SM, Bashir ZI, Collingridge GL, Lodge D (2007) Differential roles of NR2A and NR2B-containing NMDA receptors in LTP and LTD in the CA1 region of two-week old rat hippocampus. Neuropharmacology 52:60-70. CrossRef Medline

Debanne D, Gähwiler BH, Thompson SM (1999) Heterogeneity of synaptic plasticity at unitary CA3-CA1 and CA3-CA3 connections in rat hippocampal slice cultures. J Neurosci 19:10664-10671. Medline

Dudek SM, Bear MF (1992) Homosynaptic long-term depression in area CA1 of hippocampus and effects of N-methyl-D-aspartate receptor blockade. Proc Natl Acad Sci U S A 89:4363-4367. CrossRef Medline

Etherton M, Földy C, Sharma M, Tabuchi K, Liu X, Shamloo M, Malenka RC, Südhof TC (2011) Autism-linked neuroligin-3 R451C mutation differentially alters hippocampal and cortical synaptic function. Proc Natl Acad Sci U S A 108:13764-13769. CrossRef Medline

Fiala JC, Feinberg M, Popov V, Harris KM (1998) Synaptogenesis via dendritic filopodia in developing hippocampal area CA1. J Neurosci 18: 8900-8911. Medline

Fischer G, Mutel V, Trube G, Malherbe P, Kew JN, Mohacsi E, Heitz MP, Kemp JA (1997) Ro 25-6981, a highly potent and selective blocker of $\mathrm{N}$-methyl-D-aspartate receptors containing the NR2B subunit. Characterization in vitro. J Pharmacol Exp Ther 283:1285-1292. Medline

Gambrill AC, Barria A (2011) NMDA receptor subunit composition controls synaptogenesis and synapse stabilization. Proc Natl Acad Sci U S A 108:5855-5860. CrossRef Medline

Gray JA, Shi Y, Usui H, During MJ, Sakimura K, Nicoll RA (2011) Distinct modes of AMPA receptor suppression at developing synapses by GluN2A and GluN2B: single-cell NMDA receptor subunit deletion in vivo. Neuron 71:1085-1101. CrossRef Medline

Harris KM, Jensen FE, Tsao B (1992) Three-dimensional structure of dendritic spines and synapses in rat hippocampus (CA1) at postnatal day 15 and adult ages: implications for the maturation of synaptic physiology and long-term potentiation. J Neurosci 12:2685-2705. Medline

Hintsch G, Zurlinden A, Meskenaite V, Steuble M, Fink-Widmer K, Kinter J, Sonderegger P (2002) The calsyntenins-a family of postsynaptic membrane proteins with distinct neuronal expression patterns. Mol Cell Neurosci 21:393-409. CrossRef Medline

Hoerndli FJ, Walser M, Fröhli Hoier E, de Quervain D, Papassotiropoulos A, Hajnal A (2009) A conserved function of C. elegans CASY-1 calsyntenin in associative learning. PLoS One 4:e4880. CrossRef Medline

Ito I, Sakimura K, Mishina M, Sugiyama H (1996) Age-dependent reduction of hippocampal LTP in mice lacking N-methyl-D-aspartate receptor epsilon 1 subunit. Neurosci Lett 203:69-71. CrossRef Medline

Kaech S, Banker G (2006) Culturing hippocampal neurons. Nat Protoc 1:2406-2415. CrossRef Medline

Kasai H, Fukuda M, Watanabe S, Hayashi-Takagi A, Noguchi J (2010) Structural dynamics of dendritic spines in memory and cognition. Trends Neurosci 33:121-129. CrossRef Medline

Kim BG, Dai HN, McAtee M, Bregman BS (2008) Modulation of dendritic spine remodeling in the motor cortex following spinal cord injury: effects of environmental enrichment and combinatorial treatment with transplants and neurotrophin-3. J Comp Neurol 508:473-486. CrossRef Medline

Köhr G, Jensen V, Koester HJ, Mihaljevic AL, Utvik JK, Kvello A, Ottersen OP, Seeburg PH, Sprengel R, Hvalby Ø (2003) Intracellular domains of NMDA receptor subtypes are determinants for long-term potentiation induction. J Neurosci 23:10791-10799. Medline

Konecna A, Frischknecht R, Kinter J, Ludwig A, Steuble M, Meskenaite V, Indermühle $\mathrm{M}$, Engel $\mathrm{M}$, Cen $\mathrm{C}$, Mateos JM, Streit $\mathrm{P}$, Sonderegger $\mathrm{P}$ (2006) Calsyntenin-1 docks vesicular cargo to kinesin-1. Mol Biol Cell 17:3651-3663. CrossRef Medline

Kutsuwada T, Sakimura K, Manabe T, Takayama C, Katakura N, Kushiya E, Natsume R, Watanabe M, Inoue Y, Yagi T, Aizawa S, Arakawa M, Taka- hashi T, Nakamura Y, Mori H, Mishina M (1996) Impairment of suckling response, trigeminal neuronal pattern formation, and hippocampal LTD in NMDA receptor epsilon 2 subunit mutant mice. Neuron 16:333344. CrossRef Medline

Lai KO, Ip NY (2013) Structural plasticity of dendritic spines: the underlying mechanisms and its dysregulation in brain disorders. Biochim Biophys Acta 1832:2257-2263. CrossRef Medline

Laumonnier F, Bonnet-Brilhault F, Gomot M, Blanc R, David A, Moizard MP, Raynaud M, Ronce N, Lemonnier E, Calvas P, Laudier B, Chelly J, Fryns JP, Ropers HH, Hamel BC, Andres C, Barthélémy C, Moraine C, Briault S (2004) X-linked mental retardation and autism are associated with a mutation in the NLGN4 gene, a member of the neuroligin family. Am J Hum Genet 74:552-557. CrossRef Medline

Ludwig A, Blume J, Diep TM, Yuan J, Mateos JM, Leuthäuser K, Steuble M, Streit P, Sonderegger P (2009) Calsyntenins mediate TGN exit of APP in a kinesin-1-dependent manner. Traffic 10:572-589. CrossRef Medline

Matsuzaki M, Honkura N, Ellis-Davies GC, Kasai H (2004) Structural basis of long-term potentiation in single dendritic spines. Nature 429:761-766. CrossRef Medline

Matus A (2000) Actin-based plasticity in dendritic spines. Science 290:754758. CrossRef Medline

Montgomery JM, Pavlidis P, Madison DV (2001) Pair recordings reveal allsilent synaptic connections and the postsynaptic expression of long-term potentiation. Neuron 29:691-701. CrossRef Medline

Monyer H, Burnashev N, Laurie DJ, Sakmann B, Seeburg PH (1994) Developmental and regional expression in the rat brain and functional properties of four NMDA receptors. Neuron 12:529-540. CrossRef Medline

Papassotiropoulos A, Stephan DA, Huentelman MJ, Hoerndli FJ, Craig DW, Pearson JV, Huynh KD, Brunner F, Corneveaux J, Osborne D, Wollmer MA, Aerni A, Coluccia D, Hänggi J, Mondadori CR, Buchmann A, Reiman EM, Caselli RJ, Henke K, de Quervain DJ (2006) Common Kibra alleles are associated with human memory performance. Science 314: 475-478. CrossRef Medline

Pettem KL, Yokomaku D, Luo L, Linhoff MW, Prasad T, Connor SA, Siddiqui TJ, Kawabe H, Chen F, Zhang L, Rudenko G, Wang YT, Brose N, Craig AM (2013) The specific alpha-neurexin interactor calsyntenin-3 promotes excitatory and inhibitory synapse development. Neuron 80:113128. CrossRef Medline

Sheng M, Cummings J, Roldan LA, Jan YN, Jan LY (1994) Changing subunit composition of heteromeric NMDA receptors during development of rat cortex. Nature 368:144-147. CrossRef Medline

Shipton OA, Paulsen O (2014) GluN2A and GluN2B subunit-containing NMDA receptors in hippocampal plasticity. Philos Trans R Soc Lond B Biol Sci 369:20130163. CrossRef Medline

Staubli U, Lynch G (1987) Stable hippocampal long-term potentiation elicited by 'theta' pattern stimulation. Brain Res 435:227-234. CrossRef Medline

Steuble M, Gerrits B, Ludwig A, Mateos JM, Diep TM, Tagaya M, Stephan A, Schätzle P, Kunz B, Streit P, Sonderegger P (2010) Molecular characterization of a trafficking organelle: dissecting the axonal paths of calsyntenin-1 transport vesicles. Proteomics 10:3775-3788. CrossRef Medline

Steuble M, Diep TM, Schätzle P, Ludwig A, Tagaya M, Kunz B, Sonderegger P (2012) Calsyntenin-1 shelters APP from proteolytic processing during anterograde axonal transport. Biol Open 1:761-774. CrossRef Medline

Tovar KR, Sprouffske K, Westbrook GL (2000) Fast NMDA receptormediated synaptic currents in neurons from mice lacking the epsilon2 (NR2B) subunit. J Neurophysiol 83:616-620. Medline

Vagnoni A, Perkinton MS, Gray EH, Francis PT, Noble W, Miller CC (2012) Calsyntenin-1 mediates axonal transport of the amyloid precursor protein and regulates Abeta production. Hum Mol Genet 21:2845-2854. CrossRef Medline

Vicini S, Wang JF, Li JH, Zhu WJ, Wang YH, Luo JH, Wolfe BB, Grayson DR (1998) Functional and pharmacological differences between recombinant N-methyl-D-aspartate receptors. J Neurophysiol 79:555-566. Medline

Vogt L, Schrimpf SP, Meskenaite V, Frischknecht R, Kinter J, Leone DP, Ziegler U, Sonderegger P (2001) Calsyntenin-1, a proteolytically processed postsynaptic membrane protein with a cytoplasmic calciumbinding domain. Mol Cell Neurosci 17:151-166. CrossRef Medline

Yin X, Takei Y, Kido MA, Hirokawa N (2011) Molecular motor KIF17 is fundamental for memory and learning via differential support of synaptic NR2A/2B levels. Neuron 70:310-325. CrossRef Medline

Ziv NE, Smith SJ (1996) Evidence for a role of dendritic filopodia in synaptogenesis and spine formation. Neuron 17:91-102. CrossRef Medline 